\title{
Community-Based Tourism Transformation: What Does The Local Community Need?
}

\author{
Adi Suryani $^{1}$, Soedarso ${ }^{1}$, Deti Rahmawati ${ }^{1}$, Endarko ${ }^{2}$, Achmad Muklason $^{3}$, Berto Mulia Wibawa ${ }^{4}$, Siti Zahrok ${ }^{1}$ \\ ${ }^{1}$ Department of Development Studies, Institut Teknologi Sepuluh Nopember, Surabaya, Indonesia. \\ ${ }^{2}$ Department of Physics, Institut Teknologi Sepuluh Nopember, Surabaya, Indonesia. \\ ${ }^{3}$ Department of Information System, Institut Teknologi Sepuluh Nopember, Surabaya, Indonesia. \\ ${ }^{4}$ Department of Business Management, Institut Teknologi Sepuluh Nopember, Surabaya, Indonesia. \\ e-mail: adisuryani.rahman@gmail.com
}

\begin{abstract}
Tourism is a promising development sector. It has strong potentials for improving local community life quality by alleviating poverty, broadening information access, improving facilities and infrastructure, opening new and diversifying employment. Thus, today tourism is recognized as one of key sectors in development possessing multiplier effects on other sectors and contributing to other development goals attainment. This encourages many communities to initiate and run their local-scale tourism at their kampung. The development of these community-based tourisms need to be strengthened by community capacity to develop their tourism into more sustainable and competitive destinations. Moreover, the Covid19 pandemic potentially threatens tourism existence and sustainability, especially if the communities do not rapidly respond by improving their tourism capacities. This study aims to explore several factors needed by local community to foster tourism transformation. The study is concentrated on examining WPP Dalegan and Dalegan community tourism transformation needs. The data are collected through community dialog incorporated with community service program. The study identifies three primary transformation elements for fostering WPP tourism improvement. The first factor is transformational and collective community leader who provides empowerment, climate and chance for Dalegan community to participate and orients to community social changes. The second factor is Dalegan community capacity building. Dalegan tourism transformation rests on its local community to learn together and improve the quality of their tourism services and products. The third factor is development facilitation. To successfully transform, Dalegan community needs to expand their networking, build horizontal and vertical partnerships.
\end{abstract}

Keywords - Community-Based Tourism, Community Capacity Building, Tourism Development.

\section{INTRODUCTION}

$\mathrm{T}$ OURISM sector is one of component players in development. Sustainable tourism increases local people economic capacity, living condition, social, psychological and physical well being. Growing tourism industries/enterprises, particularly those managed and run by local community can potentially alleviate local peo poverty and provide chance to get better educational access, health services and living facilities. This indicates that sustainable tourism influences other development sectors.

The COVID-19 pandemic disaster has been changing the face of many tourism destinations. Many of them are threatened to end their tourism business activities temporary, even for unpredictable period of time. Pandemic hazard and health protocol regulation prohibit tourists to come and limit their access to enjoy fun recreational activities. The decreasing number of tourists reduces tourism income. Consequently, local people are involved in tourism industries are in danger of loosing their occupations which risk their family life and well being. Thus, pandemic disaster poses challenges which require stronger capacity building to recover, survive and grow. Furthermore, tourism industries and their local communities need to strengthen their mitigating and developing capacities to anticipate the future challenges. Covid 19 hits tourism and put it into significant crisis [1]. International tourism is reported as the most affected sector because of covid due to uncertain duration of virus [1]. Tourism crisis rises unemployment due to the costs of shutdowns [1]. Thus, the local communities need to be equipped with building capacities and understand the development elements. It is not just for developing pandemicbased recovery capacities, but also for the normal period. As highlighted by [2], tourism may potentially contribute to SDGs in all goals, particularly goal no 8 (decent work and economic growth), 12 (responsible consumption and production) and goal 14 (Life below water). Tourism needs to be identified and prioritized in SDGs by identifying its challenges issues [3].

This study aims to explore several development elements which potentially contribute to tourism improvement run by local community. It is focused to investigate and analyze Dalegan (as a micro destination) marine tourism development needs, which is run by Dalegan-Gresik local community.

\section{LITERATURE REVIEW}

\section{A. Roles of Local Tourism}

Tourism is reported by many researchers as one of several promising sectors, which significantly contributes to economic growth. Tourism is one of vital economic development drivers [1], [4]-[6]. Similarly, Dinu [7] confirms that economic sector is driven by tourism, telecommunication and information technology. Moreover, tourism industry and travel are designated as the income generator [7]. Meyer and Meyer [8] also discover that tourism industry can absorb low skilled workers to alleviate poverty. Tourism improvement is associated with the growing bilateral exchange, tourists' spent, macroeconomic outcomes, investment and tourism attractiveness [9] and the functions of hotels, restaurants, trade [10]. Besides supporting economic sector, tourism encourages the endurance of cultural and natural heritage, cultural creativity, cultural diversity and social-environmental balances [11].

Tourism is also indicated as one of determinant measures of development [12]. Tourism contributes to economic 
development by increasing earnings of foreign exchange, government revenues, occupation, income and development of regional areas [13], alleviating poverty [14], [15], increasing GDP (Gross Domestic Product) particularly in some sectors, such as foreign investment, development in energy and agriculture, and poverty [14]. Bunghez [5] illuminates that tourism industry brings about economic development through the job creation, implementation of tariffs and taxes and other associated sectors, including technical-material sector, infrastructural facilities, commercial, lightning, food, sport, communication and salon services sectors.

Tourism power to alleviate poverty is rooted from its multi-sectors support needs. It requires collaboration of tourism inner circle and outer circle to encourage its development. As revealed by ILO [16], tourism is a labor intensive industry which and can create diverse employment, both job directly linked to tourism (such as restaurants and hotels) and indirectly related to tourism (such as transportation, souvenir shops, tourist guide). Tourism is not only relaxing and entertaining activity, but also activity for supporting economic sector which increases job employment and prompts infrastructure improvement, such as roads, railways [17]-[19].

Tourism spreads positive effects to its surrounding fields. As reported by Oxford Economics [9, p. 4], tourism stimulates job creation and multiplier effects. Since it involves other sectors, the positive development of tourism induces the involved sectors. To develop, tourism needs to be supported by adequate transportation and travel systems [20], established tourism marketing [21], internet and communication technologies [22], brand image [23]. Similarly, UNCTAD [1] reports that tourism also contributes to immediate sectors, such as local travel, education, food, financial services.

Tourism also brings about significant impacts for local community living betterment. Tourism can promote business for poor (pro-poor). It benefits local community in various ways. As mentioned by Bunghez [5], tourism increases selling of local product, the building of souvenir and local craft shops. Besides providing economic benefits, tourism offers social service and infrastructure improvements [15] and potential environmental awareness and understanding [25]. In a broader context, tourism influences community behavior, environment, economic, taxes, services provision, social and cultural aspects and transportation [17].

\section{B. Competitiveness and Sustainability of Tourism Destination}

Recently, travelling becomes one of several basic needs. This need is heightened by the advancement of transportation technology, transportation system and communication systems. This allows people to plan and arrange their own travelling activities easier and faster than before. People travel to tourism area for different personal needs, including education, business, physical and psychological [13], meeting friends, business, health services, religious visit and personal reasons [26]. This phenomenon stimulates the growth of many local tourisms, while at the same time emerging tourism competitiveness and sustainability challenges.

Many researchers and tourism practitioners focus on exploring tourism competitiveness and its sustainability aspects. Sustainable tourism refers to tourism focuses on all resources management to address social, economic and aesthetic needs and preserve ecology, cultural integrity, biodiversity and systems for supporting life. Enormous research findings reveal the features of competitive and sustainable tourism destinations. Tourism competitiveness is defined as place capacity to maximize its features to attract residents and non-residents, provide quality, innovation and entertainment to obtain global and domestic market shares, while at the same time preserving resources and using it to support tourism sustainably [12]. The competitiveness of a destination is determined by several factors, such as confluence between pull factors (products, services, infrastructure, supplies) and push factors (image, marketing, provided experiences and perceived values) [28], tourism branding [29], sustainable quality, promotion and resource knowledge [30], brand image [23], internet, communication technologies, and travel agencies [30], tourism business to promote [31], tourism transport [32] and entrepreneurship business [4]. Tourism development also requires the intersection between tangible factors (such as strategic place, access and products) and less tangible factors (services and local people experiences) [33], tourism policy [34], and tourism marketing to increase destination popularity [35].

Competitive and sustainable tourism is supported by established management. Királ'ová and Pavlíčeka [36] illuminate the need of social media management as platforms to connect potential visitors and tourism management. Similarly, Dupeyras \& MacCallum [12] argue that tourism competitiveness tends to be dynamic and changing, such as complying to changing travelling behavior and social media. Competitive tourism also relates to development of digitalization for opening tourism access [37]. Other scholars emphasizes on the need of strategic plan management [38], tourism planning, delivering \& marketing [39], tourism destination marketing management [40], stakeholder management and challenges handling (such as environmental, economic and social inequality) [41] and destination attractiveness management (such as facilities, persons, services) [42].

Sustainable tourism is also indicated by its capacity to protect environment, while flourishing economic life. Sustainable tourism is created through the confluence of natural and human environment. As demonstrated by Mason [25], tourism is interwoven by its natural and human environment in which people environment is built by human social, cultural and economic factors, while natural environment is built by surrounding plants and animals. Tourism development needs understanding on interaction of tourism environment multitude and interdisciplinary drive [23]. Responsible and sustainable tourism impacts on environmental protection and preservation [43]. Environmental care and awareness in sustainable tourism tend to be manifested in any sectors, such as environmental protection policy [44], environmentally friendly tourism operators/enterprises [45], environment quality [43], environmental management [27], climate change education, eco friendly products and the use of culture and tradition [46]. Seyidov and Adomaitiene [47] also confirm that environment, human resource and price are some factors considered by tourist in visitation decision making. 
The development of competitive and sustainable tourism is the result of destination collaborators. One of those actors is government. Government has significant role in inviting and supervising tourism investment [48], in establishing tourism policy [34], especially in encouraging economic growth [49] and tourism promotion [50]. Local government also can support tourism sustainability through tourism policy, plan, festivals, promotion and infrastructure provision [51, p. 3], tourism plan [52]. The other actors are the co-operators, facilitators and investors. As mentioned by Buhalis [53], for increasing tourism competitiveness, it is required strategic marketing, co-operation, visibility, cost reduction. Tourism destination growth depends on investments, shared vision and development strategies [54], tourism networks-business cooperation [55], destination networking [56], partnership, various products, marketing, visibility, cost reduction and attainment of stakeholders' strategic objectives [53].

The other component is local resources. Some of those are cultural attractiveness [57], local events [58], tourism performance and the influences, capacity to provide quality services, destination attractiveness, policy and attractions [12] and various cultural resources [59]. The other local components are local people creativity (creative economy) [38] and local people involvement. As illuminated by Thetsane [60], local communities needs to be involved in policy decision making process to ensure that their needs and concerns are addressed. Thus, tourism capacity to develop also depends on exploration of local potentials [61]. Local communities are the main tourism developers [60]. Moreover, surrounding residents are the field tourism informers [62].

Currently, many local tourisms which are initiated by local communities grow in Indonesia. Tourism in Indonesia is focused to reduce poverty, create green jobs, decent works achievements, prevention of gender discrimination and child labour [38]. It is developed for three main purposes: life quality increase, social and cultural value nourishment, values added creation, while targeting the poor, growth, environment and job creation. Ministry of Tourism and Creative Economy of the Republic of Indonesia \& ILO [38] identify several key strategies implemented in Indonesia to develop its tourism, such as altering stakeholder thinking, developing indicators for sustainable tourism, habituation of green mindsets and strategic management introduction.

\section{Community Change}

To survive and grow, all communities need to embrace change. Change is a natural social phenomenon which stimulates community renewal, modification and re-structure of many community aspects. Community change can be caused by demographic change, cultural change [63], labour market, economic, people movement and environmental changes [64].

To develop competitive tourism destination, local community needs to change collectively. They need to learn together and grow as a learning community. Enormous studies examine the substantive elements needed in community change. Oetting et al [65] emphasize on the community readiness as basic requirement for community change, which includes community attitudes, action, knowledge and resources which are supported by community members and leaders. Community readiness can be diagnosed from several dimensions: community endeavors,

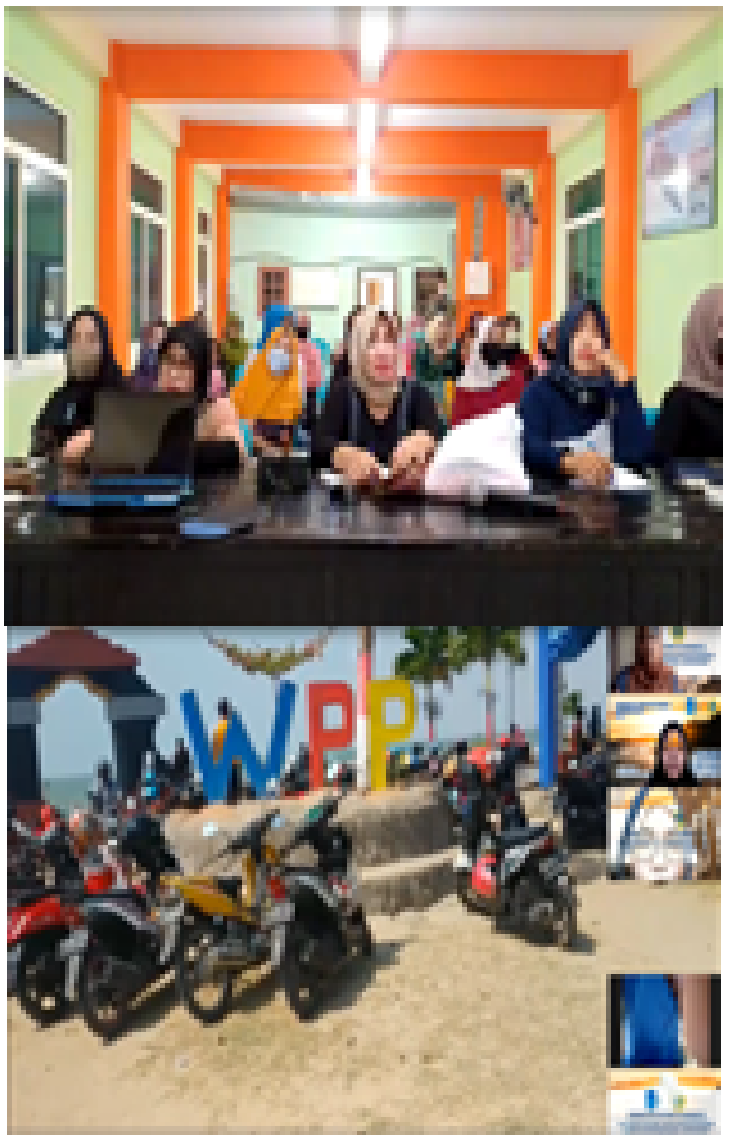

Figure 1. The participants of community service program and the WPP Dalegan in a short video played during the program

leadership, community knowledge about the efforts, community knowledge about their issues, community climate, resources [66]. How a community ready for change can be assessed through several stages, such as no awareness, rejection, vague awareness, pre-planning, preparation, initiation, stabilization, confirmation and high level of community ownership [66].

Other studies focus on exploring community capacity to embrace changes. To change, a community needs resilience as survival capacity and adaptive capacity [64], change vision, planning, capacity building and entrepreneurship skills [67], cultural change planning [68], clear vision and mission, visible changes, community leadership, sector engagement, feedback and technical support [69], urgency for change, vision and mission for change, aims of change, actions for change, power for change, assets, empowering conditions, dialog and consultants/researchers/observers [70], the community capital framework which includes human, social, political, financial, built, natural, cultural capitals [71], changing or modified programs, policies and practices [69]. Furthermore, community change can be encouraged by considering five change dimensions: participants, approach, structure, intention and parameter [72].

The heart of community change rests on local community motivation to change and participate in planning and implementing change. As mentioned by Evans and Loomis [70], change occurs only when people are gathering to make it happens. Similarly, Community Science [73] argues that to sustain change, community needs to be actively collaborate to improve their living conditions and possess resilient 
capacity. They need to care about the planned changes and engage [73] as community engagement is the key factor in community change [74]. This community engagement entails the need of strong community sense. As illuminated by Anderson \& Milligan [75], community change can only happens by developing social fabrics/social capitals, including social networks, interactions, social climate, community sense, social cohesion of the target community. Relevant to the previous findings, Born [74] identifies communities characteristics needed in encouraging change, such as collective effects, engagement, innovation, community leadership and change evaluation, while Behzad and Ahmad [76] stress the urgency of community education to create self-reliant community, while other scholar, such as Auspos and Kubish [77] identify several aspects in catering changes, such as effective community building strategies, intervention approaches, interconnected outcome areas, connection between internal community and outside world and intervention threshold.

A considerable body of knowledge suggests approaches, strategies and steps in inducing community change. Kubisch et al [78] suggest several actions to generate social change, including community reflective learning, clarity and alignment of vision, mission, expected outcomes, principles, actions, building capacity assessment and partnerships. Differently, The Youth Affairs Council of Victoria [79] emphasizes on strategy to change through youth participation (empowerment, inclusiveness and purposeful engagement). CADCA's National Coalition Institute [80] recommends seven steps for enabling community change, including supporting information, equipping skills, support, increasing access, changing impacts, changing physical design and policies. Specifically, Emery et al [71] suggest the appreciative inquiry process towards community change, which includes defining focus of change, then go down to the process of discovering positive core, envisioning visible future, designing some innovative ways, delivering the change and reflecting. Several principles in community change are developing from community vision, building community strength, managing diverse people and various sectors, encouraging collaborative leadership, experiential learning [81] and using community capitals as the assets, through asset mapping [71].

Some researchers and practitioners analyze the role of intervening strategies to facilitate community changes. Intervention by involving local community participation can be effective strategy to change community [82]. Community organizations and intervening parties can work with targeted community to accelerate changes. As mentioned by Evans \& Loomis [70], effective functioning community organizations can support change. Voluntary and community organizations, funders, informal emerging groups can be potential agents for inducing rapid change through partnership, mediating or mentoring [63]. Stoecker [83] recommends four steps in intervening community change, such as identifying condition of community, prescribing intervention, applying the plan, assessing the actions. Similarly, Anderson [84] shows several step by step in facilitating community change, including diagnosing outcome for long term, structuring ways to change, operationalizing outcome, defining interventions and conveying assumptions. Meanwhile, Hubbell \& Emery [85] focus on community coaching strategy for helping
Table 1.

Dalegan Head Village Roles In Fostering Changes

\begin{tabular}{|c|c|}
\hline \multicolumn{2}{|c|}{ Roles and Responsibilities } \\
\hline Role 1 & Representing Dalegan community \\
\hline Role 2 & Motivating them to come/participate \\
\hline Role 3 & Organizing the process/events \\
\hline Role 4 & $\begin{array}{l}\text { Bridging interaction/communication between } \\
\text { internal/Dalegan community and outside } \\
\text { community/eternal during the event preparation }\end{array}$ \\
\hline Role 5 & Inspiring change \\
\hline Role 6 & Understanding the community context/situation \\
\hline Role 7 & $\begin{array}{l}\text { Voicing/expressing Dalegan community tourism } \\
\text { development obstacles, including: financial difficulties }\end{array}$ \\
\hline Role 8 & $\begin{array}{l}\text { Attempting to explore potential solutions, such as financia } \\
\text { services for helping small and middle local enterprises }\end{array}$ \\
\hline Role 9 & Identifying community issues \\
\hline Role 10 & Communicating the current community situation/context \\
\hline Role 11 & Building partnership \\
\hline Role 12 & Expecting future collaborative/networking vision \\
\hline
\end{tabular}

community to plan changes, focus on long term vision, and implement strategic actions for change. Specifically Community Science [73] defines the intervening actions into several steps: the founding steps (providing clear direction, building trust, engaging diverse stakeholders, addressing trends, strengthening leadership, enhancing funding, creating collaborative structure, building capacity and expanding partnership), community-capacity steps (building community capacity for change-related organizing elements, considering community culture, strengthening community capacity in data access and decision making, increasing capacity to implement change, increasing focus, system change steps (targeting wider system change, creating services based for integrated place-based systems) and community context (understanding the uniqueness of the community, community prior experience.

\section{METHOD}

The study aims to explore several aspects needed to support Dalegan community changes, particularly for transforming Dalegan WPP tourism destination. Currently, WPP-Dalegan has been suffering from decreasing tourist quantity from 459,862 people in 2012 to 310.522 people in 2013. The quantitative data sign alarming situation for Dalegan local community and WPP marine tourism industry. WPP (Wisata Pasir Putih) is located in Dalegan village, at Gresik, East Java. WPP is a community-initiative based tourism. It is developed and run by Dalegan residents from children playing ground to progressively become local marine tourism. Today, Dalegan local community collaboratively attempts to increase the quality of WPP for attracting more visitors, especially during pandemic and new normal period and improve the economic condition of Dalegan local community. The following figure (Figure 1) shows some training participants are listening to the materials delivered and the situation of WPP tourism as captured in short tourism video.

The study is integrated with the authors' community service program at Dalegan on August 2020. The data are collected during the program, through material delivery and dialog with Dalegan community participants via zoom. To understand what factors needed by the targeted community to change deeper, a qualitative method is employed. Qualitative 
December $5^{\text {th }}, 2020$, Online Conference

Table 2.

The Targeted Knowledge

\begin{tabular}{ll}
\hline \hline \multicolumn{1}{c}{ Elements } & \multicolumn{1}{c}{ Knowledge } \\
\hline Social & $\begin{array}{l}\text { Strategy analysis, market penetration, market } \\
\text { development, product development, partnership } \\
\text { building, developing potentials/resources } \\
\text { (identifying strengths and barriers) }\end{array}$ \\
Branding & $\begin{array}{l}\text { Marketing foundation, brand definition, brand } \\
\text { perception, functions of brand, brand power, } \\
\text { impact of brand on product price, place branding, } \\
\\
\text { elements of successful branding, branding strategy, } \\
\text { branding media: social media, website. }\end{array}$ \\
Marketing & Marketing definition, market (definition, \\
strategy & structure), segmentation (positioning, segmentation \\
& determinants: geography, demography, \\
& psychography, product use, product usage \\
intensity), market targeting (6P=Product, Place, & Price, People, Promotions, Process and Physical \\
evidence), positioning, marketing dynamic, \\
promotion, media usage, supporting factors (local \\
culture, government, bureaucracy, cultural events, \\
tourists segmentation)
\end{tabular}

researchers attempt to explore things in social world in a deeper and broader perspective [87]. The data are collected through natural dialog with participants of community service. Qualitative researchers investigate things in natural real context [87].

The collected data are analyzed by using thematic method of analysis. The data are clustered into several themes and categories to understand their meaning, The interpreted meanings of data are also understood within the light of previous literatures. Qualitative researchers rest on researchers' interpretative approach to understand particular meaning and behavior in social world [88]. Knowledge is developed through the process of interpreting data from the field and linking them to literature. As highlighted by [88], theory in qualitative research is extracted from the field through iterative process, with the researchers as the key persons in collecting and analyzing data.

\section{RESULTS AND DISCUSSION}

The data reveal that the majority of the participants are women who sell various products, especially smoked fish and souvenirs. They express needs to increase their product sales to support family economic income. The authors identify three main themes emerging from data analysis. Those themes are leadership, community knowledge building and change facilitation.

\section{A. Transformational and Collective Leadership}

The data show that Dalegan head village contributes actively to the community service program and motivates the community to learn. The following table (Table 1. Dalegan head village roles in fostering social change) lists several key roles of Dalegan head village in fostering community change through WPP tourism transformation.

The data indicate that the head village is fostering WPP tourism changes by fulfilling three main leadership responsibilities. As illuminated by Watt [89], civic leaders orient to focus on the common goal of community and are involved in social change process.
The first role is representing his community and bridging Dalegan community. As a leader, he becomes a community bridge who channels communication/interaction between Dalegan community and external community, stakeholders/investors and development facilitators. He becomes the font liner in accepting/welcoming external partners/facilitators and in contacting/accessing external tourism developers to initiate certain networks. During the community service program execution, he motivates people to come, organizes the place, prepares facilities, ensures the execution of the program and helps community to talk/communicate their tourism development barriers. The head village exhibits his enthusiasm to support Dalegan community to learn and get new knowledge to improve WPP tourism destination. As mentioned by Giles, et. al. [90], transformational leaders benefits organization as they tend to exhibit encouragement, trust, care, involvement, agreement and facilitation. He encourages many women entrepreneurs at WPP tourism to learn how to improve their sales and create product branding for enhancing the popularity of their business products. It is reported that transformational leadership can facilitate change through mutual commitment, empowerment and collectivity [91]. Besides empowering and motivating Dalegan community to participate, he welcomes us (the authors) as the eternal facilitators who intend to share some insights on developing/creating business/product brand/image with Dalegan community. This implies that he is aware of the facilitative role of external contributors. Community change can be ensured by the development of collaborative leadership and stakeholders collaborations [92]. Moreover, strong social change roots from collective action [93], by involving parties impacting changes and people impacted by those changes [94]. The data also imply that the head village builds relationship internally and externally. As mentioned by Orians, et. al. [93], community change needs collaborative leaders as they build relationships among individuals, expand strong network, synergize networks into collective action and form networking mindset. Collective leadership rests on three principles: relational, fluid and transformational [95]. Consistently, Kellogg Foundation [95] argues that collective leaders tend to utilize technological, cultural and human potentials to collaborate community for collective well being. Effective leaders try to find ways to survive in changing environment by managing internal and external resources to respond to social changes [89].

The data show that the head village invites participants to village meeting hall to learn new things. This indicates that he communicates and organizes his community to do things together and prepares facilities to enable them to learn. Leadership is about managing people to change, communicating persuasively to different people, managing uneasiness and drive collaborative community development [96]. During the community service program, the head village helps his community to express their voices. This confirms that community leaders lead changes through dialogue, collective empowerment and connective leadership by facilitating individuals to reach goals, exploring collective potentials and relating to the goals and encouraging the growth of collective leadership [97].

The second role is being embedded with his community in natural daily interaction. As part of community members, he lives and interacts with other people. Through this daily 
social life, he has opportunities to understand the real life situation of Dalegan communities. Through this process, the leader can understand and sense the real life situation of his community. As highlighted by Kanapi and Sanchez [98], leaders need to be able to co-sensing and co-presensing to foster new structure, which is based on TLLCtransformational leadership in a learning community framework. Through this direct interaction, leaders can detect and identify local community issues, such as funding, people education or negative views towards tourism [99]. Furthermore, transformational leaders rest their leadership performance on their engagement with people and (task) delegation [100]. The data and leadership researches show that leaders' capacity to engage with their community is one of several basic needs for community social changes. As emphasized by Watt [89], successful leaders possess competence to inspire people to work together. Dalegan head village is one of community leaders who can be effective community changers as they are immersed in social network, create shared vision and decision making [99]. Leaders need to rely on their relationship capacity and obtain support from community instead of their structural power [101]. Furthermore, community engagement can be advanced by leaders by focusing and stating community engagement in vision statement, allocate resources for community engagement, formalizing community engagement and enlivening institutional commitment [102].

The third role is organizing and managing Dalegan communities and its natural/physical environment to transform positively. The collective changing process, such as in WPP tourism destination needs vision, plan and collective commitment. Leader is the one who can make changes happen through collective actions. Leaders are change agents who manage change process: plan change, define change, and skills needed to change [103]. The head village needs to build shared vision, plan and work with Dalegan community. Leadership is associated with the creation and promotion of collective vision [94] and clear vision for positive social change [104]. Leadership is about what the leaders and followers do together to manage internal and external changes [89], mutual influence, shared purposes, mutual relationship and change enactment [105]. Transformational leaders are creative problem solvers, empowering, fostering people participation through delegation, shared responsibilities, shared leadership, strengthening individual and group [106], are responsible to expand network, respond the competitive environment, customer challenges, working collaboratively, encouraging strategic thinking, product and service development [107], are drawing trust from credibility, exploring others' natural strengths to enable them to be co-leaders, caring about shared issues and fostering collective change and individual change transforming into organizational change [98], are empowering community and are participative in decision making [101].

The study shows that to transform their WPP tourism Dalegan community needs supportive community leaders who foster social changes by empowering local community, being participative, building relationship and establishing external networking. Thus, social community changes need effective community leaders. Community leaders are community change catalysts [94], [108]-[111] and contributes to SDGs [112], [113].

\section{B. Community Capacity Building}

The data show that tourism transformation needs local community participation, particularly in the context of community-based tourism. Local community is the main actor in tourism transformation. Community participation is an imperative in community based tourism [114]. Dalegan community is conscious that to improve their destination, they need to learn and increase their tourism skills and knowledge. Through community service program, the authors intend to increase Dalegan community tourism capacity building by informing/educating them some basic elements of tourism management. The following table (Table 2 , the targeted knowledge) presents several materials/knowledge delivered during the training session.

The data demonstrate that to participate in WPP tourism improvement, Dalegan community needs to collectively develop their capacity building. Some of those are by understanding tourism management knowledge, such as social mapping, branding management and tourism marketing strategy. It is important for community to strengthen their skills and knowledge to sustain development [115]. Sustainable tourism development is also attained through community empowerment in which the community understands information and having capacity to participate in decision making. Empowered community can contribute to tourism development. As identified by Musadad [116], lack of tourism competency, poverty, lack of knowledge in management policy and communication are some barriers of sustainable tourism.

Dalegan community capacity building is an imperative for WPP improvement. As mentioned by Aref and Redzuan [117], community capacity building is significant development strategies in which the community learns to manage their self through leadership facilitation, participation and collective vision. Marzuki and Khoo [118] suggest some strategies for increasing capacity building, such as training and education, projects for empowering small and medium enterprises, environmental protection and developing partnership [118]. Meanwhile, Anggahreni [119] proposes other strategies, which include providing information access, following program run by government, building horizontal partnership and network organization. Community capacity building is key determinant in tourism success which can be provided in forms of education, training on hospitality and tourism management, also business skills, such as marketing, finance, governance and communication [120] [120]. This community capacity building implicates on sustainable tourism [115].

The study also indicates that it is not sufficient for Dalegan community to know how to cook their smoked fish only. They also need to understand how to market and brand WPP to attract more tourists to come, enjoy the services and buy the products. From the training, Dalegan women participants learn how they can potentially get financial support for developing their business and how to innovatively brand their fish products. This is relevant with Zefnihan and Alhadi [121], who reports that community capacity building can be improved by education and training which is introduced in variety of forms, such as role playing, face to face training, and expert tour groups which can potentially increase people 


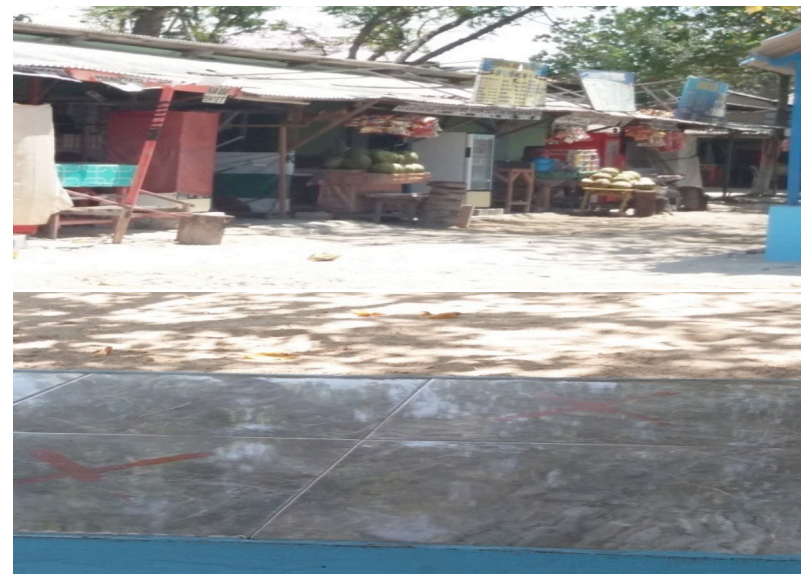

Figure 2. Food stalls at Dalegan and one of WPP Dalegan ways to implement COVID-19 health protocols

knowledge and skills [121]. By getting new knowledge, it is expected that Dalegan women entrepreneurs can increase the quality of their products. Community' increasing capacity building can be indicated from increasing quality of their products and services which also benefits their economic [121]. Capacity building empowers the community to participate in tourism development and enhances community capacity for decision making [115]. Community empowerment strengthens sustainable tourism development which is linked by community support [122]. Community can also increase their capacity from experiential learning and involvement in tourism management [121]. Moreover, building community capacity which is incorporated by other elements, such as community commitment, confidence, connection, competence are the basic requirements of community-based tourism development. Relevant to previous findings, Djou, Baiquni, Widodo and Fandeli define three basic features of community based tourism, namely community inclusion, fair economic access, community empowerment in political arena for decision making participation. Community capacity building also needs leadership support [122]. Figure 2 shows some local/traditional food stalls in WPP and how WPP Dalegan implements covid-19 health protocol to ensure the safety and health of all stakeholders.

Through dialog, Dalegan women entrepreneurs express that WPP tourism enables them to work for helping their husband in supporting family financial life. Some of those are selling smoked fish, instant food, traditional food, drink and souvenirs. Tourism development can offer livelihood diversification, such as various types of tourism business, such as souvenirs store, restaurants, food sellers, boat services and traditional art business [121]. Community based tourism stimulates the growth of local entrepreneurs and form mutual beneficial relationship [121]. They voice that many Dalegan women sell smoked fish at WPP area. This product seems to be the unique brand of WPP. Many tourists come to WPP to enjoy the white sand area and buy smoked fish as a gift for their families, neighbours and friends. Local community can contribute to tourism development by adding attractiveness and variations of their products, maintaining the uniqueness features of their tourism [121], producing local unique products and playing a role in marketing management/process [123]. Selling smoked fish is small business which is closely related to the natural environment
Table 3.

Voices From Field

\begin{tabular}{cl}
\hline \hline & \multicolumn{1}{c}{ Issues from field } \\
\hline Issue 1 & $\begin{array}{l}\text { Financial difficulties to support Dalegan women } \\
\text { entrepreneurs to expand their small and middle tourism } \\
\text { business, since they use their personal finance to run } \\
\text { their business. } \\
\text { Innovation in branding and product package for } \\
\text { marketing their local products }\end{array}$ \\
Issue 3 & $\begin{array}{l}\text { Access difficulties as they do not know how to build } \\
\text { relationship/partnership with other organizations }\end{array}$ \\
Issue 4 & $\begin{array}{l}\text { Procedures to register legal label for their products } \\
\text { Expanding new market for their various fish-related } \\
\text { products }\end{array}$
\end{tabular}

of Dalegan as maritime area, Dalegan livelihood and living ways as fishermen. As suggested by Shaw and Williams, to ensure community participation in tourism, it is significant to embed community needs and life ways with tourism development. Moreover, by empowering Dalegan women to sell smoked fish, they are involved in tourism activities. As noted by Rasoolimanesh \& Jaafar [125], community participation can be increased by involving community in economic activities and benefits sharing. They can also be encouraged to participate by giving them opportunities to work with stakeholders in planning, decision making process and implementation and are encouraged to participate in travel and entrepreneurism sectors [126], equality in benefits sharing and its access [127], advocacy [116],

The data also show that to facilitate transformation, Dalegan community needs to maintain good relationship, working and learning together. Successful transformation is not only lying on entrepreneurial tourism capacity of its residents, but also positive relationship producing harmonious, comfortable and safe tourism environment and culture. Thus, social capital also plays considerable roles in ensuring tourism development. As highlighted by Khadar et al. [128], to achieve successful tourism development, local community needs to increase its social attachment. Community who has strong social capital and cooperation and community willingness to contribute tends to be successful in developing tourism [129]. Furthermore, sense of community is a catalyst in tourism development [130].

This study shows that local community participation in tourism development is significant. This is because local communities are local key actors in tourism as they are the main service providers, such as providing accommodation, food, transportation, information and other services. They are the host and the main deliverers of tourism services and products [124]. This community participation needs to be encouraged by community empowerment and capacity building.

\section{Partnership and Collaboration}

The data convey the need to build partnership for fostering required transformation. Branding management training which is conducted by community service team only is not sufficient to assist Dalegan community to solve their complex issues. The following table (Table 3, some issues voiced from field) lists several issues voiced by Dalegan participants during the dialog. 


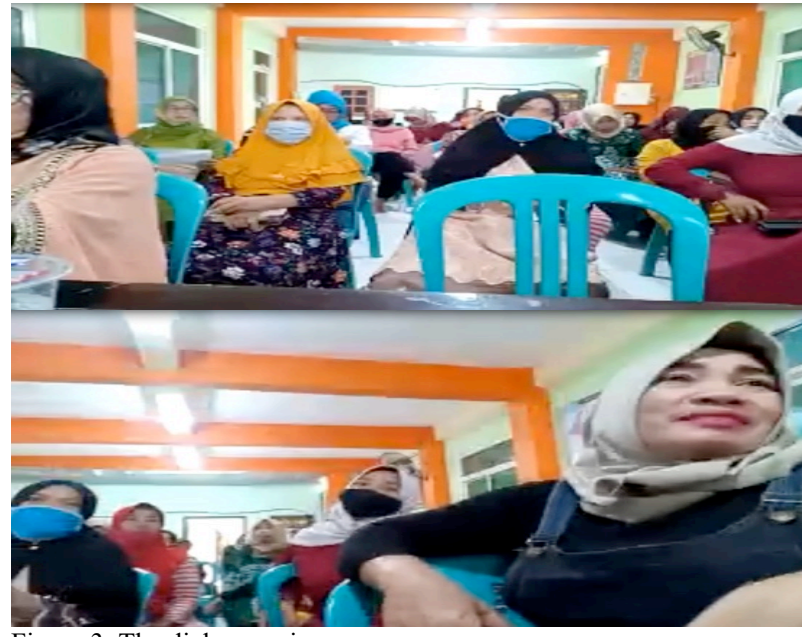

Figure 3. The dialog session

The data show that Dalegan local community faces various issues, ranging from financial, marketing, legal procedures to innovation. These various issues cannot be solved by just establishing one partnership. Instead, a multi-partnership approach is needed to address the problems. Frequently, tourism destination management needs the involvement of multiple stakeholders to assist issues emerging different fragmented activities. Moreover, stakeholders' collaboration is needed to reach competitive advantages at developed destination [131]-[133]. Figure 3 shows the enthusiasm of women participants asking and voicing their business experiences/business during the dialog session.

The data indicate that the partnerships need to be established with different organizations, across different levels and types. To overcome financial issues, Dalegan may need to partner with financing agents, such as banking, FinTechs, government bodies or industries, while issues concerning with branding innovation can be managed by collaborating with higher education for branding knowledge, industries and UMKMs practitioners for providing training and real practice or direct experience. As advised by Gazivod [131], through partnership, the local community at destination can get new capital sources, accelerate development process, access to new market, new knowledge, problem solving for issues. Partnership is needed for greater efficiency, financial support, human resources capacity, new access to market [134].

Issues related to knowledge on how to build relationships may potentially be solved by partnering with NGOs and higher education institutions, while issues on legal labeling can be handled by inviting local government (trade/commerce, industrial and health affairs departments). How to open new market issue can be solved by partnering with higher education institutions, especially faculty of economics and business, government institution and industrial organizations. It is also required to collaborate with other more experiences communities/UMKMs. Thus, different partners may have different strengths which can be collaborated collectively to create shared problem solving. As mentioned by De Lacy et al. [132], each partner brings about particular roles and advantages, such as public sectors may contribute to disseminating/informing regulation, building facilities and infrastructure, enhancing marketing and promoting, running training and education, while NGOs can participate in development assessment/monitoring, consultation, bottom-up advocacy, collecting development key players, research inputs. Inherent with previous findings, Graci [134] clarifies the benefits of implementing multistakeholder partnership approach, for instance, sharing solutions in term of incentive to protect destination environment, innovative methods to solve the issues through the process of dialogue and consultation, the emergent development strategy relevant to real context/issue. Meanwhile, KPMG Canada [135] reveals that different partnership needed to target some particular areas, such as financial, infrastructure, human resources, marketing, products, research and technology.

The data also suggest that Dalegan community needs to partner with various public and private organizations. Many scholars suggest the involvement of various partners to support tourism development. The multiple stakeholders involved can come from across different fields of private and non-private, such as local government, external business, tourists, local residents, local business, employees [134], the integrated relationship between public and private organizations [136], local government, tourism-related business and NGOs [137], public and private organizations [132], [138] and local networking [139]. By establishing multiple partnership approach, various shared benefits can be obtained. As mentioned by Kim et al. [138], the advantages gained from public-private partnerships include cost efficiency, shared risk, improved quality, increasing revenues, efficient execution.

Some data show Dalegan difficulty in finding information related to legal process and communicating with financial service institutions. This implies that Dalegan community also has an issue on partnership and collaboration management. Thus, they also need facilitation on building network and relationship. As identified by Fernandes [139], local community at destination may encounter issues relating to stakeholders and partnerships, such as enhancing communication between internal people and external organizations, more professional development trainings for local residents, and creative partnerships. Other partnership issues which need to be addressed are creating strategy for capacity building and communication in order to accommodate all stakeholders' voices for development input [140], managing partnership/how to create, maintain and regenerate collaboration [135], identifying, selecting the partners/types of partnerships [141] and ensuring development sustainability through evaluation of partnerships for long term [142]. Dalegan community also needs to understand the effectiveness and ways to assess impactful partnerships. Spink and Merrill-San identify several elements of successful partnerships, such as interrelationship, leadership, process orientation, shared responsibility, communication, problem sharing, vision, transparent decision making process, shared power and recognition and power.

The study shows that transforming tourism destination needs shared/collective and collaboration between the local community and eternal partners, since the emerging issues tend to be complex and dynamic. Thus, it needs local community to also establish fluid and dynamic partnership to address emerging issues, create more sustainable and competitive tourism. It is vital for destination to build partnership to be able to implement development strategy in 
more sustainable ways [131]. Moreover, tourism sustainability is reached by collaboration of responsible tourists, governance, CSR and citizens by involving multicrossing of public, private, local community and tourist as stakeholders [143].

\section{CONCLUSION}

Tourism is a promising development sector which can potentially alleviate poverty, accelerate economic growth, opening new employment and multiplying its effects to other sectors. Thus, currently, many community-based tourisms are flourishing in Indonesia. One of the big challenges faced by those community-based tourisms are how to transform themselves into more competitive and sustainable tourism destination. This study aims to explore what Dalegan community need to transform their WPP marine tourism. The study finds that to transform, Dalegan local community needs collective and transformational leaders who facilitate community social changes. Secondly, they also need to improve their capacity building, including various tourism management knowledge and practices. Thirdly, they need to collaborate with external partners as well as other local communities (local networks).

\section{REFERENCES}

[1] UNCTAD, "Covid-19 and tourism. Assessing the economic consequences," United Nations Conference on Trade and Development, 2020

[2] UNWTO, "Tourism and the Sustainable Development Goals," World Tourism Organization, Madrid, Spain, 2020.

[3] P. Jones, D. Hillier, and D. Comfort, "The sustainable development goals and the tourism and hospitality industry," Athens Journal of Tourism, vol. 4, no. 1, pp. 7-18, 2017, doi: 10.30958/ajt.4.1.1.

[4] C. Biswas and M. M. O. Rashid, "The role of tourism entrepreneurship businesses in the economic development: an overview," International Journal of Business and Tehnopreneurship, vol. 8 , no. 2 , pp. $167-176,2018$

[5] C. L. Bunghez, "The importance of tourism to a destination's economy," Journal of Eastern Europe Research in Business \& Economics, pp. 1-9, 2016, doi: 10.5171/2016.143495.

[6] Oxford Economics, "Travel \& Tourism as a Driver of Economic Development in Jamaica," Oxford Economics, Oxford, UK, 2012.

[7] A.-M. Dinu, "The importance of tourism and touristic services in gdp," Quaestus Multidisciplinary Research Journal, pp. 73-80, 2000.

[8] D. F. Meyer and N. Mayer, "The role and impact of tourism on local economic development: a comparative study," African Journal for Physical, Health Education, Recreation and Dance, vol. 21, no. 1:1, pp. 197-214, 2015.

[9] Oxford Economics, "Tourism: Jobs and Growth. The Economic Contribution of the Tourism Economy in the UK," Oxford Economics, London, 2013.

[10] M. Antara and M. S. Sumarniasih, "Role of tourism in economy of Bali and Indonesia," Journal of Tourism and Hospitality Management, vol. 5, no. 2, pp. 34-44, 2017, doi: $10.15640 / \mathrm{jthm} . v 5 \mathrm{n} 2 \mathrm{a} 4$.

[11] M. Robinson and D. Picard, "Tourism, Culture and Sustainable Development," UNESCO, France, 2006

[12] A. Dupeyras and N. MacCallum, "Indicators for measuring competitiveness in tourism: a guidance document," OECD Publishing, 2013/02, 2013. [Online]. Available: http://dx.doi.org/10.1787/5k47t9q2t923-en.

[13] L. J. Lickorish and C. L. Jenkins, An Introduction to Tourism. Oxford Reed Educational and Professional Publishing Ltd, 1997.

[14] A. Khan, S. Bibi, A. Lorenzo, J. Lyu, and Z. U. Babar, "Tourism and development in developing economies: a policy implication perspective," Sustainability, vol. 12, no. 1618, pp. 1-19, 2020, doi: $10.3390 /$ su12041618.

[15] N. Luvanga and J. Shitundu, "The Role of Tourism in Poverty Alleviation in Tanzania," Research on Poverty Alleviation (REPOA),
Tanzania, Research Report No. 03.4, 2003. [Online]. Available: www.mkukinanyota.com.

[16] ILO, "Developments and challenges in the hospitality and tourism sector," International Labour Organization, Geneva, Switzerland, GDFHTS/2010, 2010.

[17] G. Kreag, "The Impacts of Tourism," The University of Minnesota, Duluth.

[18] C. O. Moisă, "The importance and the role of tourism in the economic and social life of alba county," Annales Universitatis Apulensis Series Oeconomica, vol. 17, no. 1, pp. 126-140, 2015, doi: 10.29302/oeconomica.2015.17.1.10.

[19] A. Sharma, S. Kukreja, and A. Sharma, "Role of tourism in social and economic development of society," International Journal of Advanced Research in Management and Social Sciences, vol. 1, no. 3, pp. 10-31, 2012.

[20] M. Rebstock, "Economic Benefits of Improved Accessibility to Transport Systems and the Role of Transport in Fostering Tourism for All," OECD, Paris, Discussion Paper No. 2017-04, 2017.

[21] O. H. Mwinuka, "Reviewing the role of tourism marketing in successful sustainable tourist destinations," African Journal of Hospitality, Tourism and Leisure, vol. 6, no. 2, pp. 1-11, 2017.

[22] S. S. Sahoo and B. G. Mukunda, "Role of Social Media in Promoting Tourism Business - A Study on Tourism Promotion in Odisha," presented at the International Conference People Connect: Networking for Sustainable Development, 2017, [Online]. Available: www.ijcrt.org.

[23] P. S. Manhas, L. A. Manrai, and A. K. Manrai, "Role of tourist destination development in building its brand image: a conceptual model," Journal of Economics, Finance and Administrative Science, vol. 21, pp. 25-29, 2016.

[24] D. Meyer, "Tourism Routes and Gateways: Key Issues for the Development of Tourism Routes and Gateways and their Potential for Pro-Poor Tourism.," Overseas Development Institute, 2004.

[25] P. Mason, Tourism Impacts, Planning and Management. Oxford: Peter Mason, 2003.

[26] University of Pretoria, "Tourism Demand and Supply," University of Pretoria, pp. 46-111.

[27] E. Muhanna, "Sustainable tourism development and environmental management for developing countries," Problems and Perspectives in Management, vol. 4, no. 2, pp. 14-30, 2006.

[28] E. G. Küçükaltan and I. Pirnar, "Competitiveness factors of a tourism destination and impact on residents' quality of life: the case of cittaslow-seferihisar," Journal of Tourism, Heritage \& Services Marketing, vol. 2, no. 1, pp. 22-29, 2016.

[29] D. Ushakov, M. Ermilova, and E. Andreeva, "Destination branding as a tool for sustainable tourism development (the case of bangkok, thailand)," Espacios, vol. 39, no. 47, 2018

[30] I. Batinić, "The role and importance of the internet in contemporary tourism in travel agencies business," International Journal of Cognitive Research in science, engineering and education, vol. 1, no. 2, 2013, [Online]. Available: www.ijcrsee.com.

[31] R. Delgado, "The role of tourism businesses to promote local destinations in japan to attract international tourists," Ritsumeikan Journal of Asia Pacific Studies, vol. 37, pp. 46-57, 2019.

[32] F. Alasgarova, "The Role of Tourism Transport's Development in Economic Growth," 3, 2017.

[33] A. L. Negrușa and M. M. Coroș, "Destination Management Organizations' (dmos') Roles and Performance - Literature Review," Romania, 2016, pp. 267-274.

[34] A. Anszperger, "The role of public administration in tourism development in the case of the Torun County," Public Policy and Administration, vol. 16, no. 4, pp. 553-566., 2017.

[35] I. Ana, "The tourism destination marketing-a mandatory course for the students of tourism," Annals of the University of Oradea, Economic Science Series, vol. 17, no. 4, pp. 918-922, 2008.

[36] A. Királová and A. Pavlíčeka, "Development of social media strategies in tourism destination," Procedia - Social and Behavioral Sciences, vol. 175, pp. 358 - 366, 2015, doi: 10.1016/j.sbspro.2015.01.1211.

[37] OECD, "Key Findings. Tourism Trends and Policies 2020 OECD Tourism Trends and Policies 2020.," OECD, 2020. [Online]. Available: www.oecd.org/cfe/tourism.

[38] Ministry of Tourism and Creative Economy of the Republic of Indonesia and ILO, "Strategic Plan. Sustainable Tourism and Green Jobs for Indonesia," International Labour Organization, Jakarta, 2012.

[39] M. A. Camilleri, "The Planning and Development of the Tourism Product," in Tourism Planning and Destination Marketing, M.A.Camilleri., UK: Emerald Publishing Limited, 2019, pp. 1-23. 
[40] M. Soteriades, "Tourism destination marketing: approaches improving effectiveness and efficiency," Journal of Hospitality and Tourism Technology, vol. 3, no. 2, pp. 107-120, 2012, doi: $10.1108 / 17579881211248781$.

[41] H. M. Bhola-Paul, "Tourism challenges and the opportunities for sustainability: a case study of grenada, barbados, and tobago," Journal of Tourism and Hospitality Management, vol. 3, no. 9-10, pp. 204-213, 2015, doi: 10.17265/2328-2169/2015.10.004.

[42] S. Vengesayi, F. Mavondo, and Y. Reisinger, "Tourism destination attractiveness: attractions, facilities, and people as predictors,' Tourism Analysis, vol. 14, pp. 621-636, 2009, doi: 10.3727/108354209X12597959359211.

[43] U. Sunlu, "Environmental impacts of tourism," in Local resources and global trades: Environments and agriculture in the Mediterranean region, In Camarda D. \& Grassini L. (ed.)., Bari : CIHEAM, 2003, pp. $263-270$.

[44] A. Asadzadeh and M. S. S. Mousavi, "The role of tourism on the environment and its governing law," Electronic Journal of Biology, vol. 13, no. 2, pp. 152-158, 2017.

[45] GeoPark Life, "Good Practice Guide. The Role of Tourism Enterprises," GeoPark Life.

[46] M. Muhamad and A. G. Prima, "Implementation of Sustainable Tourism Destination Development Achievements (Indicators of Sustainable Tourism Development (STD), Sustainable Tourism Observatory (STO) Towards Sustainable Tourism Certification (STC) in Pulesari Village, Wonokerto, Turi District, Sleman Regency, Daerah Istimewa Yogyakarta),”2016, pp. 0121-0125.

[47] J. Seyidov and R. Adomaitienè, "Factors influencing local tourists' decision-making on choosing a destination: a case of azerbaijan," Ekonomika, vol. 95, no. 3, doi: 10.15388/ekon.2016.3.10332.

[48] I. Kunst, "The role of the government in promoting tourism investment in selected mediterranean countries - implications for the republic of croatia," Tourism and Hospitality Management, vol. 17, no. 1, pp. $115-130,2011$.

[49] A. B. Suhel, "The role of tourism toward economic growth in the local economy," Economic Journal of Emerging Market, vol. 10, no. 1, pp. 32-39, 2018.

[50] D. Ramsey, "The Role of the State in Tourism Product Development and Promotion Product Development and Promotion in Manitob." Brandon University.

[51] LGMA, CCMA, and Local Authorities Ireland, "Role of Local Government in Tourism," LGMA, CCMA, Local Authorities Ireland, 2016.

[52] N. M. Breakey, "Tourism Destination Development - Beyond Butler," Dissertation, The University of Queensland, 2005.

[53] D. Buhalis, "Marketing the Competitive Destination of the Future," University of Westminste, England, Tourism Management. [Online]. Available: http://www.wmin.ac.uk/Env/UDP/staff/buhalis.htm.

[54] United Nations, "Promoting Foreign Investment in Tourism," United Nations, New York \& Geneva, United Nations Conference on Trade and Development Series A, number 5, 2010.

[55] O. Kulusjärvi, "Resort-oriented tourism development and local tourism networks - a case study from northern finland," Fennia, vol. 194, no. 1, pp. 3-16, 2016

[56] M. Żemła, "Tourism destination: the networking approach," Moravian Geographical Reports, vol. 24, no. 2, pp. 2-16, 2016, doi: 10.1515/mgr-2016-0018.

[57] OECD, "The Impact of Culture on Tourism," OECD, 2009. [Online]. Available: www.oecd.org/publishing/corrigenda

[58] I. Mihajlović and M. Vidak, "The importance of local events for positioning of tourist destination," European Journal of Social Sciences Education and Research, vol. 4, no. 4, pp. 228-239, 2017.

[59] J. Csapó, "The role and importance of cultural tourism in modern tourism industry," in Strategies for Tourism Industry - Micro and Macro Perspectives, 2012.

[60] R. M. Thetsane, "Local community participation in tourism development: the case of katse villages in lesotho," Athens Journal of Tourism, vol. 6, no. 2, pp. 123-140, 2019, doi: 10.30958/ajt.6-2-4.

[61] A. J. Kadi, M. Jaafar, and F. Hassan, "Review of literature of the rural heritage tourism destination," SHS Web of Conference, vol. 12, no. 0100, 2014, doi: 10.1051/shsconf/20141201008.

[62] J.-E. Lim and H. R. Lee, "Living as residents in a tourist destination: a phenomenological approach," Sustainability, vol. 12, no. 1836, pp. 1-12, 2020, doi: 10.3390/su12051836

[63] M. Taylor and M. Wilson, "Changing communities: supporting voluntary and community organisations to adapt to local demographic and cultural change," The Baring Foundation, 2015.
[64] Barrow Cadbury Trust, "Adapting to Change: The Role of Community Resilience," The Young Foundation, London, 2012. [Online]. Available: www.youngfoundation.org

[65] E. R. Oetting, B. A. Plested, R. W. Edwards, P. J. Thurman, K. J. Kelly, and F. Beauvais, "Community Readiness for Community Change," in Tri-Ethnic Center Community Readiness Handbook, 2nd ed., Sage Hall: Tri-Ethnic Center for Prevention Research, Colorado University, 2014, pp. 1-43.

[66] B. A. Plested, R. W. Edwards, and P. Jumper-Thurman, Community Readiness: A handbook for successful change. Fort Collins: CO: TriEthnic Center for Prevention Research, 2006.

[67] N. Walzer, "Bringing about Community Change Collective Impact Issues," presented at the Community Development Society Annual Meetings, Lexington, 2015.

[68] C. C. Sonn, N. M. Drew, and P. Kasat, "Conceptualising Community Cultural Development: The Role of Cultural Planning in Community Change," Community Arts Network (WA) Inc, Cloisters Square, 2002. [Online]. Available: www.canwa.com.au.

[69] Good and Healthy, "Key Factors for Community Change and Improvement," South Dakota Communities.

[70] S. D. Evans and C. Loomis, "Organizational and Community Change," in Critical Psychology: An Introduction, D. Fox, I. Prilleltensky\&S. Austin (Eds.)., Sage, 2009, pp. 373-390.

[71] M. Emery, S. Fey, and C. Flora, "Using community capitals to develop assets for positive community change," CD Practice, vol. 13 , pp. 1-19, 2006.

[72] J. Dean-Coffey, N. Farkouh, and A. Reisch, "Dimensions of change: a model for community change efforts," The Foundation Review, vol. 4, no. 3, pp. 42-64, 2012, doi: 10.4087/FOUNDATIONREVIEW-D12-00010.1.

[73] Community Science, "Emerging Action Principles for Designing and Planning Community Change.," Community Science, Gaithersburg, ol. 1, No. 1, 2015 .

[74] P. Born, "Our Community can Change| When we Work Together Well," Tamarack Institute, 2016.

[75] A. A. Anderson and S. Milligan, "Social Capital and Community Building," in Community Change: Theories, Practice, and Evidence, K. FulBright-Anderson\&P. AusPos (Eds)., Washington DC: The Aspen Institute, 2006, pp. 21-59.

[76] S. Behzad and N. Ahmad, "The role of the community in community's development: promotion of self dependence through education,' African Journal of Business Management, vol. 6, no. 49, pp. 11896 11901, 2012, doi: 10.5897/AJBM10.1603.

[77] P. Auspos and A. C. . Kubisch, "Building Knowledge about community Change. Moving Beyond Evaluations," The Aspen Institute, New York, 2004. [Online]. Available: www.aspenroundtable.org.

[78] A. C. Kubisch, P. Auspos, P. Brown, and T. Dewar, "Community Change Initiatives from 1990-2010: Accomplishments and Implications for Future Work," Vol 2, Issue 2, 2010.

[79] The Youth Affairs Council of Victoria, Taking youth seriously. Creating change in your community. A handbook for young people. Melbourne: Department of Victorian Communities, 2004.

[80] CADCA's National Coalition Institute, "Defining the Seven Strategies for Community Change," CADCA's National Coalition Institute, 2016. [Online]. Available: aodpartnership.org.

[81] M. Courtney, L. Weaver, and S. Cheuy, "Reflections on Community Change| Two Countries, two Perspectives, One Vision for Moving Forward," Tamarack Institute.

[82] D. Biggs et al., "Developing a theory of change for a communitybased response to illegal wildlife trade," Conservation Practice and Policy, vol. 31, no. 1, pp. 5-12, 2016, doi: 10.1111/cobi.12796.

[83] R. R. Stoecker, Research Methods for Community Change. Madison, Chile: SAGE Publications, Inc, 2005.

[84] A. A. Anderson, "The Community Builder's Approach to Theory of Change. A Practical Guide to Theory Development," The Aspen Institute Roundtable on Community Change, New York. [Online]. Available: andreaA@aspenroundtable.org.

[85] K. Hubbell and M. Emery, "Engaging in Sustainable Community Change A Community Guide to Working with a Coach." [Online]. Available: www.communitycoaching.com.

[86] D. Rahmawati, S. Soedarso, A. Suryani, B. M. Wibowo, A. Muklason, and E. Endarko, "Pelatihan Marine Tourism Branding Berbasiskan Kearifan Lokal untuk Pariwisata yang Inklusif di Desa Dalegan Kabupaten Gresik, Jawa Timur," Institut Teknologi Sepuluh Nopember, Surabaya, Proposal, 2020. 
[87] B. Hancock, E. Ockleford, and K. Windridge, "An Introduction to Qualitative Research," National Institute for Health Research, Nottingham, 2007.

[88] C. Palmer and A. Bolderston, "A brief introduction to qualitative research," The Canadian Journal of Medical Radiation Technology, pp. 16-19, 2006.

[89] W. M. Watt, "Facilitating social change leadership theory: 10 recommendations toward effective leadership," Journal of Leadership Education, vol. 8, no. 2, pp. 50-71, 2009.

[90] C. Giles, L. Johnson, S. Brooks, and S. L. Jacobson, "Building bridges, building community: transformational leadership in a challenging urban context," Journal of School Leadership, vol. 15, no. 5, pp. 519-545, 2005.

[91] M. Chirichello, "Building Capacity for Change: Transformational Leadership for School Principals," presented at the the Annual International Congress for School Effectiveness and Improvement, San Antonio, 1999.

[92] M. Cleveland and S. Cleveland, "Building engaged communities-a collaborative leadership approach," Smart Cities, vol. 1, pp. 155-162, 2018, doi: 10.3390/smartcities 1010009 .

[93] C. Orians, A. Chew, and P. Rowland, "Evaluating Leadership for Social Change," ORS Impact, 2018.

[94] M. Creyton, "Community Leadership," QUT \& Volunteering Queensland, 2002.

[95] Kellogg Foundation, "The Collective Leadership Framework A Workbook for Cultivating and Sustaining Community Change," Kellogg Foundation, 2007.

[96] J. McNeely, S. Aiyetoro, and P. Bowsher, "The Paths to Leadership in Community Change," The Annie E. Casey Foundation, Baltimore, 1999.

[97] P. Kirk and A. M. Shutte, "Community leadership development," Community Development Journal, vol. 39, no. 3, pp. 234-251, 2004, doi: $10.1093 / \mathrm{cdj} / \mathrm{bsh} 019$.

[98] J. A. Kanapi and A. M. C. Sanchez, "Transformational Leadership in a Learning Community," A Working Paper, 2018.

[99] N. S. Chili and N. A. Ngxongo, "The role of community leadership in fostering an agenda of active community participation in rural regional tourism development: perspectives from umhlwazini," African Journal of Hospitality, Tourism and Leisure, vol. 6, no. 4, pp. 1-12, 2017.

[100]K. Sandell, “Transformational Leadership, Engagement, and Performance: A New Perspective," Master Thesis, Colorado State University, Colorado, 2012.

[101]F. Avant, K. Rich-Rice, and S. Copeland, "Leadership and rural communities," International Journal of Business, Humanities and Technology, vol. 3, no. 8, pp. 53-59, 2013.

[102]J. G. Liang and L. R. Sandmann, "Leadership for community engagement - a distributed leadership perspective," Journal of Higher Education Outreach and Engagement, vol. 19, no. 1, pp. 35-64, 2015.

[103] S. Ajmal, M. Z. Farooq, N. Sajid, and S. Awan, "Role of leadership in change management process," Abasyn Journal of Social Sciences, vol. 5, no. 2, pp. 111-124.

[104]M. J. Hao and R. Yazdanifard, "How effective leadership can facilitate change in organizations through improvement and innovation," Global Journal of Management and Business Research: A Administration and Management, vol. 15, no. 9, pp. 1-6, 2015.

[105]K. Pigg, "Thinking Anew about Community Leadership," SDRC, SRDC Series: Leadership and Civic Engagement Publication \#264.

[106]J. L. Arches, "Connecting to communities: transformational leadership from africentric and feminist perspectives," The Journal of Sociology \& Social Welfare, vol. 24, no. 4, pp. 113-124, 1997.

[107]J. Trevor and R. Hill, "Developing transformational leadership capability," Developing Leaders, vol. 9, pp. 42-47, 2012.

[108]R. Bolden and P. Kirk, "Leadership Development as a Catalyst for Social Change: Lessons from a Pan-African Programme," in Worldly Leadership: Alternative wisdoms for a complex world, Turnbull et al. (eds)., Basingstoke: Palgrave Macmillan.

[109]I. Carreras, A. Leaverton, and M. Sureda, "Leaders for Social Change Characteristics and Competencies of Leadership in NGOs," ESADE, 2009.

[110]R. Flowers and D. Waddell, Community Leadership Development Handbook. Australia: Centre for Popular Education, 2004.

[111]A. A. M. Rami, R. Abdullah, and M. H. A. Simin, "Influence of leadership in rural community development in the state of terengganu, malaysia," Asian Journal For Poverty Studies, vol. 3, no. 1, pp. 47 52, 2017, doi: 10.33369/ajps.v3i1.2669.

[112]H. A. Gabbar, N. Honarmand, and A. A. Abdelsalam, "Transformational leadership and its impact on governance and development in African nations: an analytical approach," Journal of Entrepreneurship \& Organization Management, vol. 3, no. 2, pp. 1000121-1000121, 2014.

[113]WHO, "Open Mindsets: Participatory Leadership for Health," World Health Organization, France, 2016.

[114]A. Giampiccoli and M. Saayman, "Community-based tourism development model and community participation," African Journal of Hospitality, Tourism and Leisure, vol. 7, no. 4, 2018, [Online]. Available: http//: www.ajhtl.com.

[115]F. Ahmeti, "Building community capacity for tourism development in transitional countries: case of Kosovo," European Journal of Scientific Research, vol. 115, no. 4, pp. 536-543, 2013.

[116]Musadad, "Community participation in nature tourism development: lessons from pindul cave in yogyakarta, indonesia," Kawistara, vol. 8, no. 2, pp. 111-212, 2018, doi: 10.22146/kawistara.27957.

[117]F. Aref and M. B. Redzuan, "Tourism development for community capacity building and community development," TEAM Journal of Hospitality \& Tourism, vol. 5, no. 1, pp. 68-72, 2008.

[118]A. Marzuki and J. Khoo, "Community development strategies for tourism development in langkawi islands, malaysia," in From Empirical Research Towards Practical Application, 2016, pp. 15-29.

[119]Y. Anggraheni, Hermawan, and Sujarwoto, "Understanding community participation within sustainable rural tourism development (a case study in kalibiru village, yogyakarta special region, indonesia)," Jurnal Ilmiah Administrasi Publik, vol. 4, no. 4, pp. 301-309, 2018.

[120]R. Dodds, A. Ali, and K. Galaski, "Mobilising knowledge: determining key elements for success and pitfalls in developing community based tourism," Current Issues in Tourism, vol. 21, no. 13, pp. 1547-1568, 2016.

[121]Zefnihan and Z. Alhadi, "Community-based tourism development viewed from economic, social culture and environment aspects in mandeh's integrated marine tourism area," MATEC Web of Conferences, vol. 229, 2018, doi: 10.1051/matecconf/201822901006.

[122]S. Khalid, M. S. Ahmad, T. Ramayah, J. Hwang, and I. Kim, "Community empowerment and sustainable tourism development: the mediating role of community support for tourism," Sustainability, vol. 11, no. 6248,2019 , doi: $10.3390 /$ su1 1226248

[123]M. Karmilah, W. Nuryanti, N. Soewarno, and B. Setiawan, "Community involvement in tourism development: as strategy for poverty alleviation after the earthquake (case study: Kasongan Village Yogyakarta)," International Journal of Scientific and Research Publications, vol. 4, no. 12, pp. 1-7, 2014.

[124]www.cabi.org, "The Why and How of Community-Led Tourism Development." www.cabi.org.

[125]S. M. Rasoolimanesh and M. Jaafar, "Community Participation toward Tourism Development and Conservation Program in Rural World Heritage Sites," in Tourism - From Empirical Research Towards Practical Application, Leszek Butowski (Edt)., In Tech, 2016, pp. 1-14.

[126]S. Moyo and T. M. Tichaawa, "Community involvement and participation in tourism development: a zimbabwe study," African Journal of Hospitality, Tourism and Lei sure, vol. 6, no. 1, pp. 1-15, 2017.

[127]M. Michael, “Community Involvement and Participation in Tourism Development in Tanzania A Case Study of Local Communities in Barabarani Village, Mto wa Mbu, Arusha-Tanzania," Master Thesis, the Victoria University of Wellington, 2009.

[128]N. Z. A. Khadar, M. Jaafar, and D. Mohamad, "Community involvement in tourism development: a case study of lenggong valley world heritage site," SHS Web of Conferences, vol. 12, no. 01094, pp. 1-7, 2014, doi: 10.1051/shsconf/20141201094.

[129]P. Claiborne, "Community Participation in Tourism Development and the Value of Social Capital -the case of Bastimentos, Bocas del Toro, Panamá," Master Thesis, Uniersity of Gothenburg, 2010.

[130]F. Aref, "Sense of community and participation for tourism development," Life Science Journal, vol. 8, no. 1, pp. 20-25, 2011.

[131]D. Gazivoda, "An Analysis of Stakeholders' Collaboration in Destination: The Case of Montenegro," Master Thesis, University of Ljubljana, 2014.

[132]T. De Lacy, M. Battig, S. Moore, and S. Noakes, "Public/Private Partnerships for Sustainable Tourism Delivering A Sustainability Strategy for Tourism Destinations," APEC, Singapore, 2002.

[133]A. Fathimath, "The Role of Stakeholder Collaboration in Sustainable Tourism Competitivenss: The Case of Auckland, New Zealand," Thesis, Auckland University of Technology, 2015.

[134]S. Graci, "Collaboration and partnership development for sustainable tourism," Tourism Geographies, vol. 15, no. 1, pp. 25-42, 2013. 
The $2^{\text {nd }}$ International Conference on Global Development - ICODEV

December $5^{\text {th }}, 2020$, Online Conference

[135]KPMG Canada, "Co-operation and Partnerships in Tourism: A Global Perspective," WTO, Spain, 2003.

[136]T. Jamal and A. Stronza, "Collaboration theory and tourism practice in protected areas: stakeholders, structuring and sustainability,' Journal of Sustainable Tourism, vol. 17, no. 2, pp. 169-189, 2009, doi: 10.1080/09669580802495741.

[137]A. M. Cameron, A. Memon, D. G. Simmons, and J. R. Fairweather, "Evolving Role of Local Government in Promoting Sustainable Tourism Development on the West Coast," Lincoln University, Report No. 28, 2001.

[138]D.-K. Kim, C. Kim, and T.-H. Lee, "Public and Private Partnership for Facilitating Tourism Investment in the APEC Region," APEC Working Group, Singapore, TWG 01 / 2004, 2005.

[139]C. Fernandes, "The Role of Local Networking in Facilitating Community Tourism Development," in Book of Proceeding Vol II, Portugal, 2011, vol. 2, pp. 1020-1024.
[140]T. Charleen, M. Kumbirai, and K. Forbes, "Collaboration and stakeholder involvement for tourism development in zimbabwe," International Journal of Advanced Research in Management and Social Sciences, vol. 3, no. 1, pp. 1-9, 2014.

[141]C. Ashley, C. Poultney, G. Haysom, D. McNab, and A. Harris, "How to...? Tips and tools for South African tourism companies on local procurement, products and partnerships. Brief 3: Building local partnerships," Overseas Development Institute and Business Linkages in Tourism, 2005.

[142]L. Roberts and F. Simpson, "Developing partnership approaches to tourism in Central and Eastern Europe," Journal of Sustainable Tourism, vol. 7, no. 3 \& 4, pp. 314-330, 1999.

[143]I. Slivar, "Stakeholders in a tourist destination - matrix of possible relationships towards sustainability," Open Journal for Research in Economics, vol. 1, no. 1, pp. 1-10, 2018. 